\title{
Rевенгсн Nоте: Impact of front line demonstration on turmeric in Mahasamund district of Chhattisgarh
}

\section{SAKET DUBEY, KUNAL CHANDRAKAR, S.K. VERMA AND RAVISH KESHRI}

Article Chronicle:

Received :

09.08.2017;

Accepted :

29.10.2017

\section{KeY Words :}

Extension gap, FLD,

Turmeric, Technology gap, Technology

index
SUMMARY : A front line demonstration was conducted at five farmers field in Mahasamund district of Chhattisgarh during Kharif 2016-17 to demonstrate the improved package of practice of Turmeric (Curcuma longa). There were two treatments in which one was local check and was cultivation of turmeric with full package of practice.The result revealed that local check gives a yield of $182 \mathrm{q} / \mathrm{ha}$. while turmeric cultivation with full package of practices gives a yield of $241 \mathrm{q} / \mathrm{ha}$. which shows that by adopting package of practices there were $32 \%$ increase in yield. The rhizome weight per plant recorded to be $184 \mathrm{~g}$ in local check against a $224 \mathrm{~g}$ in demonstration field. Similarly net return was also calculated which shows that local check gives a net income of Rs. 179400/ ha with a B:C ratio of 2.38 against a net income of Rs. 259700 with B:C ratio of 2.73 in demonstration field. The extension gap recorded was 59 per cent during the period of study.

How to cite this article : Dubey, Saket, Chandrakar, Kunal, Verma, S.K. and Keshri, Ravish (2017). Impact of front line demonstration on turmeric in Mahasamund district of Chhattisgarh. Agric. Update, 12(4): 732-734; DOI : 10.15740/HAS/AU/12.4/732-734.
Author for correspondence :

\section{SAKET DUBEY}

Krishi Vigyan Kendra, Bhalesar, MAHASAMUND (C.G.) INDIA

Email:saketdubey_horti@ rediffmail.com

See end of the article for authors' affiliations 